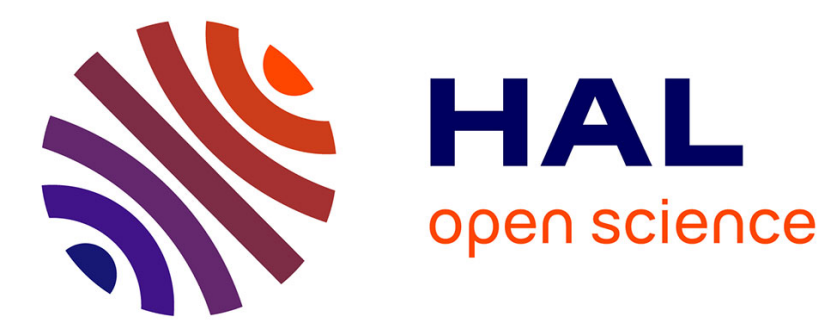

\title{
Clarifying the nomenclature of some Euro-Mediterranean quillworts ( Isoetes, Isoetaceae): Indicator species and species of conservation concern
} Angelo Troia, Germinal Rouhan

\section{To cite this version:}

Angelo Troia, Germinal Rouhan. Clarifying the nomenclature of some Euro-Mediterranean quillworts ( Isoetes, Isoetaceae): Indicator species and species of conservation concern. Taxon, 2018, 67 (5), pp.996-1004. 10.12705/675.10 . hal-02017650

\section{HAL Id: hal-02017650 \\ https: / hal.sorbonne-universite.fr/hal-02017650}

Submitted on 13 Feb 2019

HAL is a multi-disciplinary open access archive for the deposit and dissemination of scientific research documents, whether they are published or not. The documents may come from teaching and research institutions in France or abroad, or from public or private research centers.
L'archive ouverte pluridisciplinaire HAL, est destinée au dépôt et à la diffusion de documents scientifiques de niveau recherche, publiés ou non, émanant des établissements d'enseignement et de recherche français ou étrangers, des laboratoires publics ou privés. 
1 Clarifying the nomenclature of some Euro-Mediterranean quillworts

2 (Isoetes, Isoetaceae): indicator species and species of conservation

3 concern

4

$5 \quad$ Angelo Troia ${ }^{1}$ \& Germinal Rouhan ${ }^{2}$

61 Dipartimento di Scienze e Tecnologie Biologiche Chimiche e Farmaceutiche

7 (STEBICEF), Sezione di Botanica ed Ecologia Vegetale, Università degli Studi di

8 Palermo, via Archirafi 38, I-90123 Palermo, Italy

92 Institut Systématique Evolution Biodiversité (ISYEB), Muséum national d'Histoire

10 naturelle, CNRS, Sorbonne Université, EPHE, 16 rue Buffon, Herbier national CP

Author for correspondence: Angelo Troia, angelo.troia@unipa.it

ORCID AT, https://orcid.org/0000-0001-5193-8865

DOI https://doi.org/

Abstract To stabilize the application of some names in the genus Isoetes in the Mediterranean biodiversity hotspot, we studied herbarium specimens and imaged spores with scanning electron microscopy, with special reference to those taxa in the $I$. longissima Bory and I. histrix Bory groups that were described from France, Algeria and Turkey, and are in need of a taxonomic revision. The following names are lectotypified: I. adspersa A.Braun, I. boryana Durieu, I. delalandei J.Lloyd, and I. viollaei Hy. Holotypes of I. perralderiana Durieu \& LeTourn. ex Milde and I. olympica A.Braun were ascertained. We conclude that I. boryana (listed in the 'Bern Convention' and in the European Union 'Habitats' Directive) justifies consideration at species rank, but I. adspersa should be synonymized with I. longissima. Isoetes tenuissima Boreau and $I$. perralderiana are proposed as distinct species pending further studies. In the $I$. histrix group, we tentatively accept I. delalandei as a species, presenting some observations on I. histrix f. subinermis Durieu nom. nud. The latter might also represent a distinct species.

Keywords conservation; Europe; Isoetes; lycophytes; Mediterranean; taxonomy 


\section{INTRODUCTION}

The lycophyte genus Isoetes L. includes approximately 250 extant species distributed worldwide (Troia \& al., 2016; PPG I, 2016) that are the remnants of one of the most ancient extant lineages of vascular plants, diverged from Selaginella P.Beauv. as early as the Devonian Era (Pigg, 2001; Larsén \& Rydin, 2016; Klaus \& al., 2017). For this reason, they are of great evolutionary importance (Karol \& al., 2010; Doyle, 2013; Petersen \& Burd, 2017). They also have significant ecological importance because their presence in aquatic habitats such as lakes, rivers and temporary wetlands serves as indicators of superior ecological conditions in those habitats (e.g. Bagella \& Caria, 2013; Lumbreras \& al., 2016; Sciandrello \& al., 2016). These species are also of conservation concern given that most are rare or threatened; for example, García Criado $\&$ al. (2017) report that 10 out of 20 species occurring in Europe have been assessed as threatened.

In the western Mediterranean area, Isoetes longissima Bory (= I. velata A.Braun, following Troia \& Greuter, 2014) is one of the physically largest and most significant Isoetes species, both phylogenetically (it is nested in a clade including not only Mediterranean, but also African, Indian and Western North American taxa; Larsén \& Rydin, 2016; Pereira \& al., 2017) and ecologically (e.g. Grillas \& al., 2004). It is recognized, however, to be 'a taxonomically difficult suite of species, which merits further research' (Christenhusz \& al., 2017). For the purposes of this study, hereafter we refer to this species as I. longissima s.l. or the I. longissima group.

Isoetes longissima s.l. includes useful indicator species for Mediterranean seasonal wetland ecosystems, or 'Mediterranean temporary ponds' that are a conservation priority habitat according to the European 'Habitats' Directive (European Commission, 2013). Mediterranean temporary ponds (and, in general, 'temporary waters', following Williams, 2006) are of major conservation concern because, despite their small size, they shelter many rare and endangered species of both flora and fauna (Grillas \& al., 2004). They are experiencing an alarming rate of decline and population degradation (Zacharias \& Zamparas, 2010).

Due to their small size and simple community structure, temporary pools are often considered as early warning systems of the ecological implications of long-term changes in larger aquatic systems (De Meester \& al., 2006). Thus, species of Isoetes are good indicators for endangered habitats, but they themselves are species of conservation concern. Isoetes boryana Durieu, for example, is listed in Appendix 1 of the Convention on the Conservation of European Wildlife and Natural Habitats ('Bern Convention') and in the annexes II and IV of the mentioned 'Habitats' Directive. It and the other European Isoetes tenuissima have been assessed as 'Endangered' according to IUCN criteria (Christenhusz \& al., 2017, as well as Rouhan \& Christenhusz, 2017).

The Isoetes histrix Bory group is another taxonomically complicated group (Bagella \& al. 2015, Troia \& Greuter 2014, 2015a). In addition to I. histrix, it includes several 
taxa whose taxonomic rank and morphological distinctness need further investigations, all occurring in seasonally waterlogged soils.

As a general rule, species of Isoetes are very difficult to distinguish by general morphological appearance because of their simple, conserved morphology, providing few usefully distinguishing characters. Attempts were made in the past to arrange Isoetes species in groups based on ecological or morphological criteria: for instance, the Braun's system used habitats to distinguish aquatic, amphibian and terrestrial species (Grenier \& Godron, 1855), while the Pfeiffer's 'modern' system is based on the ornamentation of the megaspores (Pfeiffer, 1922). Recent phylogenetic studies (e.g. Larsén \& Rydin, 2016) show how artificial these systems are and that they are unable to correctly reflect phylogenetic relationships because of the previously mentioned conserved morphology. Similarly, I. andicola (Amstutz) L.D. Gómez was originally treated in the distinct genus Stylites Amstutz on the grounds of its morphology, but was later moved into Isoetes when both anatomical (Gómez-Pignataro, 1980) and molecular evidence (Larsén \& Rydin, 2016) showed that it was deeply nested within the large American clade. An accurate study of morphology, ideally considering other available data from anatomy, ecology, genetics etc., is therefore the basis for any taxonomic analysis.

In this study, we examined taxa within the two groups mentioned above, $I$. longissima (s.1.) and I. histrix (s.1.), with special reference to those taxa (described from France, Algeria and Turkey) that are in need of a taxonomic revision. Taxa from Spain, Italy and Greece have been studied by several authors in recent years (Prada, 1983; Romero \& al. 2004; Romero \& Real, 2005; Troia \& Greuter, 2014; Troia \& Greuter, $2015 b$ ), and all the other names in those groups have already been typified.

The taxonomic status of Isoetes boryana, a species of great conservation concern, is especially unclear. It is uncertain if it is a 'good species' (as reported in the 'Habitats' Directive, and by other sources such as Christenhusz \& Raab-Straube, 2013) or a synonym of other species (as suggested by e.g. Prelli, 2002, and Romero \& Real, 2005).

As a first step, we studied dried specimens preserved in several European herbaria, with the primary aim of stabilizing the application of names by typifying them. Thanks to scanning electron microscopy (SEM) investigations of spores removed from the types, it was possible to draw realistic morphological and taxonomic conclusions from original material or from specimens collected in the loci classici (topotypes)

\section{MATERIALS \& METHODS}

Our study is based on relevant literature and on the herbarium collections, especially those housed in the Paris Herbarium (P), with significant additional data deriving from B, FI and PAL, and from selected specimens in ANG, BM, G, GOET, KFTA, MO, MPU, NTM, US, W (acronyms according to Thiers, 2017). 
For some critical taxa, megaspore and (whenever possible) microspore features were observed with the assistance of SEM imagery. Spores were transferred with dissecting needles from herbarium specimens to aluminium SEM stubs coated with an asphalt adhesive. The stubs were then coated with gold/palladium in a sputter-coater for 2.5 min, and spores were examined using a JEOL 840 A SEM microscope, equipped with an image-digitising system (SEMAFORE software) at the Muséum national d'Histoire naturelle (MNHN) in Paris, France. The accelerating voltage was $10.0 \mathrm{kV}$. Some other samples were observed and photographed at the University of Palermo, as above, using an Oxford Leo 440 SEM. Terms used for describing the ornamentation of megaspore and microspore perines follow Lellinger \& Taylor (1997).

We employed the following species concept: a morphologically and/or ecologically distinct population (or populations), represented by all the specimens available in collections (even if few), is tentatively treated as a distinct species (considering these traits as evidence of the 'existence as a separately evolving metapopulation lineage', according to De Queiroz, 2007). Clarification of these designations awaits additional data from other sources and in particular data from further observations of living plant populations, and from the addition of molecular phylogenetic evidence. In this sense, we are essentially following the 'Typological Species Concept', sometimes with sufficient confidence to satisfy a 'Morphological Species Concept' while aiming for representation of a more complete 'Biological Species Concept' (Hickey \& al., 1989).

Because of paucity of morphological characters for distinguishing species within the genus, we found it difficult if not impossible to assess (phylo)genetic affinities to a sufficiently fine enough level to refer one taxon as a subspecies of another. Such limitations likely explain why, with few exceptions (e.g. Brunton \& Britton, 2006), infraspecific ranks so frequently employed in the past (e.g.: Engelmann, 1882; Pfeiffer, 1922; Proctor, 1949) have recently been used scarcely in Isoetes (e.g.: Christenhusz \& Raab-Straube, 2013).

\section{RESULTS}

Results are arranged according to the chronological order of publication of names, partitioned into two taxonomic groups: the Isoetes longissima group and the I. histrix group. For each name, we report information about types (designating lectotypes and epitypes whenever appropriate) and assess taxonomic value. SEM spore images are presented and commented upon whenever appropriate.

\section{Isoetes longissima group}


Taxa considered in this group include Isoetes boryana, I. olympica A.Braun, I. tiguliana Gennari, I. asturicensis (M.Laínz) M.Laínz, I. fluitans M.I.Romero, and I. longissima with its currently recognized five subspecies I. longissima subsp. longissima, I. longissima subsp. adspersa (A.Braun) Troia \& Greuter, I. longissima subsp. intermedia (Trab.) Troia \& Greuter, I. longissima subsp. perralderiana (Milde) Troia \& Greuter, I. longissima subsp. tenuissima (Boreau) Troia \& Greuter (Raab-Straube \& Raus, 2014; Troia \& al., 2016). The main distinguishing character shared by all of these taxa is the megaspore ornamentation. From an ecological point of view, the group includes both amphibian and aquatic species. A few taxa hitherto studied in molecular phylogenetics show close evolutionary relationships (Larsén \& Rydin, 2016; Pereira \& al., 2017), but most of the taxa here listed have still to be included in such analyses. Most species that have been studied karyologically (I. asturicensis, I. longissima subsp. longissima, I. olympica) are diploid, with the only exception being I. fluitans, which is a tetraploid (Troia \& al., 2016). Apart from the taxa here investigated, all other names listed above have already been typified elsewhere (in the respective protologues for the recently described taxa, or in Troia \& Greuter, 2014).

Isoetes longissima Bory in Compt. Rend. Hebd. Séances Acad. Sci. 18: 1165. 1844. 三 Isoetes velata var. longissima (Bory) A.Braun in Bory \& Durieu, Expl. Sci. Algérie, Atlas: tab. 37, fig. 2. 1849. $\equiv$ Isoetes velata subsp. longissima (Bory) Greuter \& Burdet, Med-Checklist 1: 5. 1984. - Lectotype (designated by Troia \& Greuter in Pl. Biosyst. 148: 15. 2014): [ALGERIA] 'La Calle, fond d'une Mare dans les Forets pres du Lac Houbéira', 31 May 1841, M.C. Durieu ex herb. Bory St Vincent s.n. (P barcode P00466542!; isolectotype: P barcode P00466541! p.p., detached leaves on the right) - Image of lectotype available at https://science.mnhn.fr/institution/mnhn/collection/p/item/p00466542.

\section{= Isoetes setacea var. peyrremondii Bory in Compt. Rend. Hebd. Séances Acad. Sci.} 18(26): 1165.1844 - Type: not designated.

The protologue of the name Isoetes setacea var. peyrremondii is supposed to have been published in late June or on July $1^{\text {st }} 1844$, based on issue 26 of the $18^{\text {th }}$ tome of the 'Compt. Rend...' having already been printed on July $1^{\text {st }}$, according to page 50 of the following issue (Compt. Rend. Hebd. Séances Acad. Sci. 19). Among the material present in $\mathrm{P}$, we could not locate any specimen that fits both the date and description of the protologue ('recueillie par M. le capitaine Durieu au bord des flaques d'eau des champs de la plaine d'Oran, où elle persiste jusqu'en mai...' [Algeria]) and belonging to the Bory's herbarium. One possible candidate is P01224865 ('Isoetes lineolata n. sp. Is. setacea b Perreymondii Bory. Algerie. Oran. Flaque desséchée de la plaine, 5 Juin $1844^{\prime}$ ) but it is excluded as potential original material by a note on the upper border of the label ('portée le 20 oct 1844 à la maison par Durieu'= brought to the house on $20^{\text {th }}$ Oct. 1844 by Durieu) indicating that Bory did not see this material until after the name 
was published. Another specimen collected by Durieu on 12 June 1844 (P00214778), cannot be categorically ruled out as original material, but it is unlikely given that the specimen was collected only a few days before the publication of the name.

Specimens MPU015448, MPU015449, MPU015450 (and probably many other specimens in several herbaria) were collected by Durieu on 9 June 1841 . These are compatible with the publication date of the new variety, but are labelled 'Isoetes adspersa', a synonym for Isoetes longissima that was used in the 'Flora selecta exsiccata' by Magnier. Accordingly, there is no evidence that Bory saw and used those specimens for the description validating I. setacea var. peyrremondii. We refrain from neotypifying this latter name because we cannot exclude the possibility that undetected original material still exists.

A few years after the description of Isoetes setacea var. peyrremondii, Bory raised it to the species level (as I. capillacea Bory, see below).

$$
\text { = Isoetes capillacea Bory, in Compt. Rend. Hebd. Séances Acad. Sci. 23: } 620 \text { (619-). }
$$

1846 - Type: not designated.

Bory decided that his Isoetes setacea var. peyrremondii was worthy of a species rank, basing this new species on the previously described variety and on its type (International Code of Nomenclature (ICN) art. 7.4, McNeill \& al., 2012). Unfortunately, as discussed above, we did not find unambiguous original material. Our review of Bory's (1844) diagnosis, in conjunction with our study of herbarium specimens identified by him and representing this taxon, provide us with no evidence of a clear morphological distinction between this taxon and Isoetes longissima (s. str.). On that basis, we do not recognize this as distinct from I. longissima (this latter name having nomenclatural priority).

= Isoetes adspersa A. Braun in Bory \& Durieu, Expl. Sci. Algérie, Atlas: t. 37, fig. 3. 1849 - Lectotype (designated here): [illustration] tab. 37, fig. 3, in Bory \& Durieu, Expl. Sci. Algérie, Atlas, 1849. - Epitype (designated here): [ALGERIA] mares de la plaine aux environs d'Oran, 5 Juin 1844, (M.C. Durieu) (B barcode B 200096547 ! isoepitypes: B barcode B 200096544 ! P barcode P01224865! - other original material: B barcode B 20 0096550!). — Image of lectotype available at http://bibdigital.rjb.csic.es/ing/Libro.php?Libro=3962\&Pagina=39; image of epitype available at http://herbarium.bgbm.org/object/B200096547. According to ICN art. 38.8 (McNeill \& al., 2012), the name of the species is validly published because it was accompanied by an illustration 'with analysis', i.e. with details aiding identification. According to ICN art. 9.8 (McNeill \& al., 2012), however, an epitype has been designated to serve as an interpretative type, because many morphological and microscopic details cannot be verified on the illustration chosen as lectotype. 
According to the details shown in the illustration that is part of the original material and here selected as lectotype, the following diagnostic traits should separate Isoetes adspersa from I. longissima: velum reduced (vs. almost complete); microspores non aculeate (vs. aculeate); sporangia spotted (vs. non spotted); macrospores smaller. In fact, our observations of the remaining original material suggest that macrospore and microspore distinctiveness cannot be distinguished (neither in size nor in ornamentation) (Fig. 1). The velum in the two taxa is variable in extent but always present. The presence of spotted sporangia seems to be the only consistently distinctive feature, but we occasionally observed such pigmentation in other taxa also, such as $I$. boryana, I. tenuissima, I. tiguliana. Finally, the ecology of the two taxa is identical.

Further work is needed on both fresh and dried material (epitype included), to clarify the significance, if any, of the wide range of variability we noted in the spore ornamentation of these two taxa. Based on available evidence, however, we do not believe it would be reasonable to treat Isoetes adspersa as separate from I. longissima. In addition, on the basis of the material we examined in the Braun herbarium (B), we

= Isoetes velata [unranked] intermedia Trab. in Battandier \& Trabut, Fl. Algérie Tunisie: 407. 1905 - Holotype: [ALGERIA] Dans une mare au-dessus de BouSfer, 30 Mai 1890, J.B.E. Clary (MPU008563 [image!]). - Image of type available at https://science.mnhn.fr/institution/um/collection/mpu/item/mpu008563. Roux (2009) indicated a specimen collected in Morocco in 1936 ('Morocco. In lacuna oropedii calcarei Atlantis Medii prope castellum Ito, R. Maire \& L. Emberger s.n., MPU002740, holo.') as 'holotype' of this name. This actually is the type of another infraspecific taxon, Isoetes velata f. immaculata Emb. \& Maire. That same specimen is also erroneously listed by El Oulalidi \& al. (2012) as the 'holotype' of I. velata A.Br. subsp. intermedia (Trab.) Maire \& Weiller,

We did not locate other original material of Isoetes velata [unranked] intermedia, and assumed specimen MPU008563 as to be the holotype. Regardless, we conclude that this name is most probably a heterotypic synonym of $I$. adspersa A.Braun (=I. capillacea Bory $=$ I. longissima Bory). Dobignard (2017) rightly commented on the difficulty in differentiating the subspecies of I. longissima Bory.

Isoetes tenuissima Boreau in Bull. Soc. Industr. Angers 21: 269. 1851. - Type: not designated. We could not find original material in P or in ANG. Observations made on specimens collected in the locus classicus (étang de Richaudron, commune d'Azat [Haute-Vienne, France]) highlight distinctive morphological characters (compared to Isoetes longissima) such as the plant having 
leaves of reduced size (usually (4-)8-10 cm long vs. (5-) $15-35 \mathrm{~cm}$ ) and thickness (ca. $0.5 \mathrm{~mm}$ at mid-length vs. $1-1,5 \mathrm{~mm}$ ), with a very small margin at the base.

Megaspores (Fig. 1) are significantly different from those illustrated in Berthet \& Lecocq (1977), but the specimens they used were not from the locus classicus. Spores are not particularly different from those of Isoetes longissima, although in the distal hemisphere of the megaspore tubercles are more isolated and scattered.

Isoetes tenuissima can also be distinguished from I. longissima by its ecology, typically growing in a completely submerged habitat (Prelli, 2002) vs. the seasonally dry condition of the latter. We believe the above described differences in leaf features to be also significant. Finally, the climatic, bioclimatic and biogeographic aspects could support the separation of the temperate I. tenuissima from the mediterranean $I$. longissima. Based on this evidence, we tentatively recognize I. tenuissima at the species rank while recognizing the need for further studies.

\section{= Isoetes viollaei Hy in J. Bot. (Morot) 7: 432. 1893 - Lectotype (designated here):} [FRANCE] (Haute-Vienne) Etang granitique de Riz-Chauvron commune d'Azat, Chaboisseau, September 1857, Hariot, S.E.E.F. 1892, n. 219 (P barcode P01266653!). Remaining syntypes: [FRANCE] Haute-Vienne: étang de RizChauvron, 10 septembre 1863, M.C. Durieu [Flora selecta exsiccata publié par G. Magnier, 1046 bis 'I. tenuissima' Durieu] (MPU barcodes MPU013779, MPU013780, n.v.; PAL No. 18672 !; KFTA No. 0003233, n.v.). - Image of lectotype available at http://coldb.mnhn.fr/catalognumber/mnhn/p/p01266653. Heterotypic synonym of I. tenuissima Boreau (Pfeiffer, 1922; Rouhan \& Christenhusz, 2017).

Isoetes boryana Durieu in Bull. Soc. Bot. France 8: 164. 1861 - Lectotype (designated here): [FRANCE] Etang de Cazau à Sanguinet (Landes), 23.9.1860, M.C. Durieu [labelled in Durieu's handwriting] (P barcode P00321072!, one gathering made of 6 individuals at the top half of the sheet); the lectotype is currently mounted on the same sheet with P00321071 (4 individuals only, at the bottom half of the sheet). Isolectotypes: B barcodes B 20 0107144!, B 20 0107155!; P barcodes P00202858!, P00321070!, P00334209!, P01250372!, P01255124!, P01268425!, P01297113!, P01302029!, P06141802!; PAL No. 18589! — Image of lectotype available at http://coldb.mnhn.fr/catalognumber/mnhn/p/p00321072.

The plants used by Durieu to describe his new species are in Paris (P). Pfeiffer (1922: 116) cited as 'type' some herbarium sheets stored in MO (barcode 1164548) and US (barcode 01100849), cited as: 'Etang de Cazau, Landes, 7 September, 1863, Durieu (Mo. Bot. Gard. Herb, and U.S. Nat. Herb.)'. In view of the post-publication date (1863) of that collection, it cannot be considered original material.

At $\mathrm{P}$, in addition to two specimens dated from 1858 with a printed label, we located 10 collections that are part of the original material dated from September 1860.

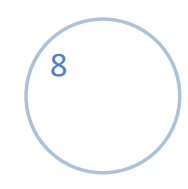


Many of these specimens were collected on 23 Sept 1860 and distributed through various channels, such as the plant exchange society 'Société Dauphinoise'.

The label of the material distributed by Schultz simultaneously reports two dates, one (3 Sept 1860) is compatible with original material while the other (14 Jul 1861) is more recent than the protologue publication date and is excluded from considerations of the type.

In the protologue, published in June 1861 (Leussink, 1985: 586), the species is said to have been discovered in 1860, and first announced to the public during a meeting of the Société Botanique de France in March 1861 when Durieu presented his new species and distributed some specimens to the members of the Société. See also the note page 165 of the same 'Bulletin de la Société Botanique de France' in which the protologue appears for additional information on the publication date.

Microspores present one of the most challenging mysteries of this taxon. Some authors described the microspores of Isoetes boryana as either smooth (Hy 1894, Berthet \& Lecocq 1977, Rolleri \& Prada 2007) or very minutely scabrid (Berthet \& Lecoq 1977, Jermy \& Akeroyd 1993) or sub-papillose (Rolleri \& Prada 2007). Prelli (2002) and Romero \& Real (2005), however, reported echinate miscropores, similar to those of I. longissima. Our investigations found only non-echinate microspores (Fig. 1). The microspore of I. boryana shown in Romero \& Real (2005) is different, however, from the microspore of I. longissima (the two are shown side by side in the same article).

Prada \& Rolleri (2005) found another character separating Isoetes boryana from I. velata/longissima, i.e. the lack of Intercellular Pectic Protuberances (IPP) in the cells of the translacunar diaphragms of the microphylls. In addition, I. boryana is deemed distinctive by its lack of persistent leaf scales (Rolleri \& Prada 2007).

Another uncertainty of this taxon is its chromosome number: it was reported to be tetraploid, $2 \mathrm{n}=44$, according to Prada ('unpubl. data' in Rolleri \& Prada 2007), but preliminary investigations with flow cytometry suggest a DNA content corresponding to a diploid level (R.Viane, com. pers.), as in I. longissima. The small megaspore diameter (ca. $450 \mathrm{~mm}$ ) and size comparable to cytologically confirmed associate taxa (Fig. 1) also argue for diploid cytology in this species.

Pending further studies, on the basis of the morphological features discussed above and especially the dramatically different ecology of this taxon, we believe Isoetes boryana to be distinct from I. longissima. Isoetes boryana is a permanently submerged aquatic species or, when occasionally growing emerged, is found only in saturated soil (Prelli 2002). Isoetes longissima is 'amphibious', growing in temporary (seasonal) pools and spends some (summer) months dormant and without leaves.

Isoetes perralderiana Durieu \& LeTourn. ex Milde, Fil. Eur.: 282. 1867 - Holotype: [ALGERIA] Sub aqua crescens in stagnulo aquis a fonte Aïn Sumta fluentibus semper replete, infra fauces Akfadou, ad occidentem Urbis Bougie Kabyliae 
orientalis, circiter ad $1250 \mathrm{~m}$. alt., 1 August 1861, E. Cosson (B barcode B 20 0108215,_specimen b!). Isotypes: B barcodes B 200108215 a!, B 200108214 !, FI!, P barcodes P00466543!, P01268221!, W barcode W0000512 (image!), GOET barcode GOET008812 (image!), G barcodes G00349116 (n.v.), G00349117 (n.v.), BM barcode BM001176369 (n.v.). - Image of holotype available at http://herbarium.bgbm.org/object/B200108215_b.

This species is known from a single collection. The protologue mentions a specimen, collected by Cosson and stored in the herb. Braun: the specimen cited above as the holotype is the only one in B fitting the protologue. Specimen P00466543 in P, which has been labelled as the 'holotype', and the specimen in the Gray herbarium mentioned as 'type' by Pfeiffer (1922) are in fact isotypes.

Our SEM imagery (Fig. 1) highlights a peculiar ornamentation of the megaspores, especially in regards to the distal hemisphere ornamentation pattern.

Being known from a single collection and its status not recently confirmed increases the urgency for further data on this species, whether it is extant, and if so, its morphological variability. On the basis of its macro- and micro- morphology as currently understood and its distinctive ecology (a true aquatic, even in mid summer), we consider Isoetes perralderiana to be distinct from I. longissima. It does, however, show some affinity with I. tiguliana.

Isoetes olympica A.Braun in Milde, Fil. Eur.: 285. 1867 - Holotype: [TURKEY] In kleinen Lachen auf dem Granitplateau des Olymps bei Brussa in Bithynien, ca. 1800 m, 22 June 1866, K. von Fritsch (B barcode B 20 0108203!). - Image of holotype available at http://herbarium.bgbm.org/object/B200108203

\section{Isoetes histrix group}

This group includes Isoetes histrix, I. gymnocarpa (Gennari) A.Braun, I. sicula Tod., I. delalandei J.Lloyd, I. subinermis (Gennari) Cesca \& Peruzzi, I. chaeturetii Mendes. Only I. delalandei remains untypified.

These species share the presence of phyllopodia (black, indurate remains of dead leaves encircling the leaf rosette at its base) and similar habitats (usually seasonally wet or flooded soils); the taxa hitherto analysed in molecular phylogenetics (Larsén \& Rydin, 2016; Pereira \& al., 2017) showed conflicting results (two accessions of I. histrix

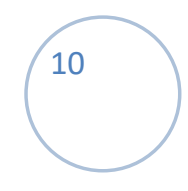


were retrieved in two non-closely related clades, probably due to misidentifications Larsén \& Rydin, 2016) and/or inaccurate morphological delimitation of the taxa. Caryological data suggest $2 \mathrm{n}=20$ for $I$. histrix and $2 \mathrm{n}=22$ for I. gymnocarpa (Troia \& al., 2016), but some recent counts suggesting distinction of another taxon similar to $I$. gymnocarpa with $2 \mathrm{n}=20$ (Bagella \& al., 2015) leaves cytological and taxonomic relationships unresolved amongst these taxa.

Isoetes delalandei J. Lloyd, Notes fl. ouest France: 28-30. 1852 - Lectotype (designated here): [FRANCE] île de Houat (Morbihan), April 1852, J. Lloyd (ANG, herb. James Lloyd) (image!); isolectotypes: B barcode B 200107589 !, NTM! (herb. Toussaint, herb. Menier), P barcodes P01313472!, P01293646!, PC0731960!

The publication date of this species name, contrary to what is reported by several sources (including Stafleu \& Cowan, 1981) is likely not 1851 but 1852, according to the Lloyd's comments in the protologue. It is also possible to read 'avril 1852' at the end of the protologue, page 30 of the 'Notes'.

As it is possible to deduce by reading the protologue, Lloyd received only two specimens (collected in May 1850 in the island of Houat) from Delalande, but given the description including precise information of the habitat, he needed to see more specimens and their habitats before describing the new species; for that, he waited until April 1852 when he was able to personally visit the sites. Accordingly, we consider plants collected in April 1852 to be part of the original material set. Other original material consists of plants collected in May 1850 by Delalande. Those plants and other collected in April 1852 in Belle-Ile are preserved in ANG.

Another specimen (in B) from the same collection is the type of another taxon, Isoetes histrix [unranked] solitaria A.Braun, so far treated as a synonym of I. histrix (Troia \& Greuter, 2014) but now to be treated as a synonym of I. delalandei.

Megaspores of I. delalandei (Fig. 2) are almost laevigate, and thus clearly different from the typical megaspores of I. histrix as well as those of I. gymnocarpa (Troia \& Greuter, 2015a: 25). Plants of this species are small (about 3-4 cm tall), with arched leaves and abundant phyllopodia exhibiting short lateral teeth.

Isoetes histrix f. subinermis Durieu in Bull. Soc. Bot. France 8: 164. 1861, nom. nud.

No typification has been made, given that the name was not validly published (Troia \& Greuter 2014). Because the name has been however widely used in literature and herbaria, we made observations on the unequivocal population noted by Durieu ('bords de l'étang de Cazau' [France]), as an incidental contribution towards disentangling the morphological variation found within the Isoetes histrix group, and towards clarifying the species concept behind that invalid name. Thus, we found that megaspores (Fig. 2) are not tuberculate, as usually seen in I. histrix, but somehow similar to a rugate type (apparently deriving from the fusion of tubercles, and for some

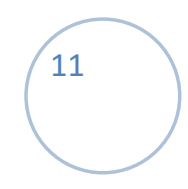


aspects resembling the retate type, typical of I. durieui Bory). In the literature it is possible to find SEM images of megaspores of 'I. histrix' s.l. (e.g. Berthet \& Lecoq, 1977; Ferrarini \& al., 1986), but unfortunately we don't know to what 'morphotype' they correspond. The only images useful for comparison of this atypical expression with other known morphotypes of $I$. histrix illustrate polar images of megaspores of $I$. histrix and I. gymnocarpa collected in Sicily (Troia \& al., 2012 and Troia \& Greuter, 2015a), and images from the type of I. gymnocarpa in Sardinia (Troia \& al., 2015). For comparison purposes, we included in Fig. 2 images of spores from specimens gathered in the (African) locus classicus of I. histrix f. loricata A.Braun representing 'true' $I$. histrix (s. str.).

\section{CONCLUSIONS}

Our morphological observations on the types or on original material or material from the 'locus classicus' help to clarify our knowledge of these two species complex. Now that the morphological and nomenclatural framework is clearer, genetic investigations could significantly further clarify the taxonomic significance of each of the taxa identified here. Further updating of knowledge of the distribution, ecology, and morphological variability of these taxa, particularly with the benefit of fresh material, will be especially useful to this endeavor.

In summary, in the Isoetes longissima group, while I. boryana and I. olympica seem deserving of species rank, I. adspersa (better treated as a synonym of I. capillacea) seems indistinct from I. longissima. It is more difficult to decide upon a taxonomic rank for I. tenuissima and I. perralderiana, which we propose to treat as separate species pending further investigations. It is important to note that I. longissima is amphibious, spending a portion of its annual cycle submerged, then becoming emergent, and finally becoming leafless and dormant after its habitat has completely dried up. In marked contrast, both I. boryana and I. tenuissima (and perhaps I. perralderiana as well) are permanent aquatics, most plants being submerged even during the summer, though some individuals can remain non-dormant as emergent on saturated soils.

In the Isoetes histrix group, the possibility exists that I. delalandei and the plants treated under I. histrix f. subinermis nom. nud. represent two taxa different from each other and both distinct from I. histrix. For the present, we accept I. delalandei as a distinct species. Further dedicated and multidisciplinary macro- and micromorphological, ecological, and molecular investigations are needed. These need to be applied to all the other taxa described in this group.

\section{ACKNOWLEDGEMENT}


480

481

482

483

484

485

486

487

488

489

490

491

492

493

494

495

496

497

498

499

500

501

502

503

504

505

506

507

508

509

510

511

512

513

514

515

516

Most of these conclusions result from research by AT in Paris (MNHN) funded by a SYNTHESYS European Grant (project 'FR-TAF 5506: The Isoetes longissima group in France and Algeria'). Additional conclusions result from additional research by AT at the herbarium of the Botanic Garden and Botanical Museum Berlin (grant code A/14/01588), funded by the German Academic Exchange Service (Deutscher Akademischer Austausch-Dienst, DAAD). Thanks are due to Géraldine Toutirais (MNHN) for assistance with SEM, and Virginie Bouetel (SYNTHESYS FR-TAF manager) for kind assistance and support before and during the work in Paris. We are indebted to colleagues of the herbaria consulted, especially Myriam Gaudeul (MNHN, Paris, P), Brigitte Zimmer (Emeritus Curator of Pteridophytes, B), Marie-Laure Guérin (Muséum d'Histoire Naturelle de Nantes, NTM), and Thomas Rouillard (Muséum des Sciences Naturelles, Angers, ANG) for their help in accessing the specimens in their care. AT also acknowledges Annie and Rémy Prelli for having kindly led him to visit on the field the population of I. boryana, Ronnie Viane for sharing his preliminary results, and Carmela Di Liberto (Università di Palermo, Dip. STEBICEF) for assistance with SEM for some specimens. We are thankful to the Editor, Dr Erin Tripp, and two anonymous reviewers, for valuable comments and suggestions on a previous version of this manuscript, and to Daniel Brunton (Ottawa, Ontario, Canada) for the assistance with linguistic issues.

\section{AUTHOR CONTRIBUTIONS}

Conceptualization: A.T. Investigation: A.T., G.R. Writing (original draft): A.T., G.R. Writing (review and editing): A.T., G.R. Visualization: A.T. Authors gave final approval of the version to be submitted and any revised version.

\section{LITERATURE CITED}

Bagella, S. \& Caria, M.C. 2013. Sensitivity of ephemeral wetland swards with Isoetes histrix Bory to environmental variables: implications for the conservation of Mediterranean temporary ponds. Aquat. Conserv. 23: 277-290. doi: 10.1002/aqc. 2290

Bagella, S., Peruzzi, L., Caria, M.C. \& Filigheddu, R. 2015. Unraveling the taxonomy and nomenclature of Isoetes histrix Bory species complex (Isoetaceae, Lycopodiidae). Turk. J. Bot. 39: 383-387. doi:10.3906/bot-1404-121

Berthet, P. \& Lecocq, M. 1977. Morphologie sporale des especes francaises du genre Isoetes L. Pollen \& Spores 19: 329-349. 
Brunton, D. F. \& Britton, D.M. 2006. Isoetes melanopoda spp. silvatica (subsp. nov.), a new quillwort (Isoetaceae) from eastern North America. Castanea 71: 15-30.

Christenhusz, M. \& Raab-Straube, E. von. 2013. Lycopodiophytina. In: Euro+Med Plantbase - the information resource for Euro-Mediterranean plant diversity. Published on the Internet. http://ww2.bgbm.org/EuroPlusMed/ (accessed 30 Oct 2017)

Christenhusz, M., Lansdown, R.V., Bento Elias, R., Dyer, R., Ivanenko, Y., Rouhan, G., Rumsey, F. \& Väre, H. 2017. Isoetes boryana. The IUCN Red List of Threatened Species 2017: e.T161833A85430458. http://dx.doi.org/10.2305/IUCN.UK.2017-2.RLTS.T161833A85430458.en (accessed 30 Oct 2017).

De Meester, L., Declerck, S., Stoks, R., Louette, G., Van De Meutter, F., De Bie, T., Michels, E., Brendonck, L. 2006. Ponds and pools as model systems in conservation biology, ecology and evolutionary biology. Aquat. Conserv. 15(6): 715-725. doi: 10.1002/aqc.748

De Queiroz, K. 2007. Species concepts and species delimitation. Syst. Biol. 56 (6): 879-886.

Dobignard A. 2017. Flore du Maroc. Published on the Internet www.floramaroccana.fr (accessed 30 Oct 2017).

Doyle, J.A. 2013. Phylogenetic analyses and morphological innovations in land plants. Pp. 1-50 in: Ambrose B.A. \& Purugganan M. (eds.), Annual Plant Reviews Volume 45: The Evolution of Plant Form. Chichester, West Sussex, UK : John Wiley \& Sons, Ltd. doi: 10.1002/9781118305881.ch1

El Oualidi, J., Khamar, H., Fennane, M., Ibn Tattou, M., Chauvet, S. \& Taleb, M.S. 2012. Checklist des endémiques et spécimens types de la flore vasculaire de l'Afrique du Nord. Documents de L'Institut Scientifique no. 25. Rabat: Université Mohammed V-Agdal.

Engelmann, G. 1882. The Genus Isoetes in North America. Trans. St. Louis Acad. Sc. 4: 358-390.

European Commission. 2013. Interpretation Manual of European Union Habitats EUR28. [Bruxelles] : European Commission, DG Environment, Nature ENV B.3, http://ec.europa.eu/environment/nature/legislation/habitatsdirective/docs/Int_Manual EU28.pdf

Ferrarini, E., Ciampolini, F., Pichi Sermolli, R.E.G., Marchetti, D. 1986. Iconographia Palynologica Pteridophytorum Italiae. Webbia 40: 1 - 202.

García Criado, M., Väre, H., Nieto, A., Bento Elias, R., Dyer, R., Ivanenko, Y., Ivanova, D., Lansdown, R., Molina, J.A., Rouhan, G., Rumsey, F., Troia, A., Vrba, J. \& Christenhusz, M.J.M. 2017. European Red List of Lycopods and Ferns. Brussels, Belgium: IUCN. http://dx.doi.org/10.2305/IUCN.CH.2017.ERL.1.en

Gómez-Pignataro, L.D. 1980. Vegetative reproduction in a Central American Isoetes (Isoetaceae). Its morphological, systematic and taxonomical significance. Brenesia 18: 1-14. 
Grenier, M. \& Godron, M. 1855. Flore de France, 3 (1). Paris: Baillière.

Grillas, P., Gauthier, P., Yavercovski, N. \& Perennou, C. 2004. Mediterranean Temporary Pools; Volume 1 - Issues relating to conservation, functioning and management. Le Sambuc, Arles: Station biologique de la Tour du Valat.

Hickey, R.J., Taylor, W.C., Luebke, N.T. 1989. The species concept in Pteridophyta with special reference to Isoetes. Am. Fern J. 79: 78-89.

Hy, F. 1894. Note sur les Isoetes amphibies de la France centrale. J. Bot. (Morot) 8: 9298.

Jermy, A.C. \& Akeroyd, J.R. 1993. Isoetes L. Pp. 6-7 in: Tutin, T.G., Burges, N.A., Charter, A.O., Edmondson, J.R., Heywood, V.H., Moore, D.M., Valentine, D.H., Walters, S.M. \& Webb, D.A. (eds.), Flora Europaea, ed. 2, vol. 1. Cambridge: University Press.

Karol, K.G., Arumuganathan, K., Boore, J.L., Duffy, A.M., Everett, K.D., Hall, J.D., Hansen, S.K., Kuehl, J.V., Mandoli, D.F., Mishler, B.D., Olmstead, R.G., Renzaglia, K.S., Wolf, P.G. 2010. Complete plastome sequences of Equisetum arvense and Isoetes flaccida: implications for phylogeny and plastid genome evolution of early land plant lineages. BMC Evol Biol. 2010, 10: 321-10.1186/14712148-10-321.

Klaus, K.V., Schulz, C., Bauer, D.S. \& Stützel, Th. 2016. Historical biogeography of the ancient lycophyte genus Selaginella: early adaptation to xeric habitats on Pangea. Cladistics 33: 469-480. doi: 10.1111/cla.12184

Larsén, E. \& Rydin, C. 2016. Disentangling the phylogeny of Isoetes (Isoetales), using nuclear and plastid data. Int. J. Pl. Sci. 177: 157-174. doi: 10.1086/684179.

Lellinger, D.B. \& Taylor, W.C. 1997. A classification of spore ornamentation in the Pteridophyta. Pp. 33-42 in: Johns R.J. (ed.), Holttum Memorial Volume. Kew: Royal Botanic Gardens.

Leussink, J.A. 1985. The publication dates of the Bulletin de la Société Botanique de France (vols. 1-25, 1854-1878). Taxon 34: 573-606.

Lumbreras, A., Marques, J. T., Belo, A. F., Cristo, M., Fernandes, M., Galioto, D., Machado M., Mira, A., Sá-Sousa, P., Silva, R., Sousa, L.G., Pinto-Cruz, C. 2016. Assessing the conservation status of Mediterranean temporary ponds using biodiversity: a new tool for practitioners. Hydrobiologia 782: 187-199. doi: 10.1007/s10750-016-2697-7

McNeill, J., Barrie, F.R., Buck, W.R., Demoulin, V., Greuter, W., Hawksworth, D.L., Herendeen, P.S., Knapp, S., Marhold, K., Prado, J., Prud'homme van Reine, W.F., Smith, G.F., Wiersema, J.H. \& Turland, N.J. 2012. International Code of Nomenclature for algae, fungi and plants (Melbourne Code) adopted by the Eighteenth International Botanical Congress Melbourne, Australia, July 2011. Regnum Vegetabile 154: 1-240.

Pereira, J.B.S., Labiak, P.H., Stützel, T. \& Schulz, C. 2017. Origin and biogeography of the ancient genus Isoëtes with focus on the Neotropics. Bot. J. Linn. Soc. 185: 253-271. https://doi.org/10.1093/botlinnean/box057

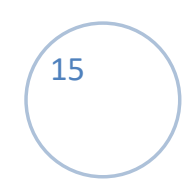


601

602

603

604

605

606

607

608

609

610

611

612

613

614

615

616

617

618

619

620

621

622

623

624

625

626

627

628

629

630

631

632

633

634

635

636

637

638

639

640

641

Petersen, K.B. \& Burd, M. 2017. Why did heterospory evolve? Biol. Rev. Camb. Philos. Soc. 92(3): 1739-1754. doi: 10.1111/brv.12304.

Pfeiffer, N.E. 1922. Monograph of the Isoetaceae. Ann. Missouri Bot. Gard. 9: 79-232. http://dx.doi.org/10.2307/2990000

Pigg, K.B. 2001. Isoetalean lycopsid evolution: from the Devonian to the present. Am. Fern J. 91: 99-114.

PPG I. 2016. A community-derived classification for extant lycophytes and ferns. $J$. Syst. Evol. 54 (6): 563-603. doi: 10.1111/jse.12229

Prada, C. 1983. El genero Isoetes L. en la Peninsula Iberica. Acta Bot. Malacit. 8: $73-$ 100.

Prada, C. \& Rolleri, C.H. 2005. A new species of Isoetes (Isoetaceae) from Turkey, with a study of microphyll intercellular pectic protuberances and their potential taxonomic value. Bot. J. Linn. Soc. 147 (2): 213- 228. https://doi.org/10.1111/j.1095-8339.2005.00362.x

Prelli, R. 2002. Les Fougères et plantes alliées de France et d'Europe occidentale. Paris: Belin.

Proctor, G.R. 1949. Isoetes riparia and its variants. Amer. Fern J. 39: 110-121.

Raab-Straube, E. von \& Raus, Th. (eds.) 2014. Euro+Med-Checklist Notulae, 3 [Notulae ad floram euro-mediterraneam pertinentes 32]. Willdenowia 44: 287 - 299. https://doi.org/10.3372/wi.44.44211

Rolleri, C.H. \& Prada, C. 2007. Caracteres diagnosticos foliares en Isoetes (Pteridophyta, Isoetaceae). Ann. Missouri Bot. Gard. 94: 202-235. https://doi.org/10.3417/0026-6493(2007)94[202:CDFEIP]2.0.CO;2

Romero, M.I., Amigo, J. \& Ramil, P. 2004. Isoetes fluitans sp. nov.: The identity of Spanish plants of 'I. longissimum'. Bot. J. Linn. Soc. 146: 231-236. https://doi.org/10.1111/j.1095-8339.2004.00315.x

Romero, M.I. \& Real, C. 2005. A morphometric study of three closely related taxa in the European Isoetes velata complex. Bot. J. Linn. Soc. 148: 459-464. https://doi.org/ 10.1111/j.1095-8339.2005.00419.x

Rouhan, G. \& Christenhusz, M. 2017. Isoetes tenuissima. The IUCN Red List of Threatened Species 2017: e.T98140004A98140117. http://dx.doi.org/10.2305/IUCN.UK.2017-2.RLTS.T98140004A98140117.en. (accessed 27 Dec 2017).

Roux, J.P. 2009. Synopsis of the Lycopodiophyta and Pteridophyta of Africa, Madagascar, and neighbouring islands. Strelitzia 23. Pretoria: South African National Biodiversity Institute.

Sciandrello, S., Privitera, M., Puglisi, M. \& Minissale, P. 2016. Diversity and spatial patterns of plant communities in volcanic temporary ponds of Sicily (Italy). Biologia 71 (7): 793-803. https://doi.org/10.1515/biolog-2016-0096.

Stafleu, F.A. \& Cowan, R.S. 1981. Taxonomic Literature. A selective guide to botanical publications and collections with dates, commentaries and types, vol. 3, ed. 
2. Regnum Vegetabile 105: 1-980. Available from: http://www.sil.si.edu/digitalcollections/tl-2/index.cfm (accessed 1 Oct 2017)

Thiers, B. 2017. [continuously updated]: Index herbariorum: a global directory of public herbaria and associated stai. New York Botanical Garden's virtual herbarium. - Published at http://sweetgum.nybg.org/ih/ (accessed 30 Oct 2017).

Troia, A. \& Greuter, W. 2014. A critical conspectus of Italian Isoëtes (Isoetaceae). Pl. Biosyst. 148: 13-20. https://doi.org/10.1080/11263504.2013.878409

Troia, A. \& Greuter, W. 2015a. Isoetaceae (vers. 1.0). In: Peruzzi L., Cecchi L., Cristofolini G., Domina G., Greuter W., Nardi E., Raimondo F.M., Selvi F. \& Troia A. (eds.), Flora critica d'Italia. Firenze: Fondazione per la Flora Italiana. Published online on 25 february 2015 at: http://www.floraditalia.it/pdf/Isoetaceae.pdf (accessed 30 Oct 2017).

Troia, A. \& Greuter, W. 2015b. A conspectus of and key to Greek Isoetes (Isoetaceae), based on a reassessment of Haussknecht's gatherings of 1885. Willdenowia 45(3): 391-403. https://doi.org/10.3372/wi.45.45303

Troia, A., Bazan, G. \& Schicchi, R. 2012. Micromorphological approach to the systematics of Mediterranean Isoetes species (Isoetaceae, Lycopodiophyta): Analysis of the megaspore surface. Grana 51: 35-43. https://doi.org/10.1080/00173134.2011.637131

Troia, A., Raimondo F.M., \& Greuter, W. 2015. Lycopodiidae for the 'Flora Critica d'Italia': material and methods. Biodivers. J. 6: 215-218.

Troia, A., Taylor, W.C., Kim, C. \& Pereira, J.B. 2016. The genus Isoetes (Isoetaceae): a provisional checklist of the accepted and unresolved taxa. Phytotaxa 277 (2): 101-145. http://dx.doi.org/10.11646/phytotaxa.277.2.1

Williams, D.D. 2006. The biology of temporary waters. New York: Oxford University Press.

Zacharias, I. \& Zamparas, M. 2010. Mediterranean temporary ponds. A disappearing ecosystem. Biodivers Conserv (2010) 19: 3827-3834. https://doi.org/10.1007/s10531-010-9933-7

\section{Legends of the figures}

Fig. 1. SEM images of megaspores and microspores of (from the first to the fourth line) Isoetes longissima (specimen B96539) Isoetes adspersa (specimen P01224844), I. tenuissima (specimen P01266657), I. boryana (specimen P06141802), I. perralderiana (specimen P01268222). For each taxon, from left to right: megaspore proximal view,

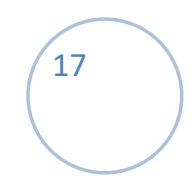


681 megaspore distal view, megaspore equatorial view, microspore. SEM micrographs of 682 the first taxon made by AT and Carmela Di Liberto (at the University of Palermo), the 683 other ones made by AT (in P).

684

685

686

Fig. 2. SEM images of megaspores of (from the first to the third line) I. delalandei

687 (P01313472), I. histrix f. subinermis (P01649801), I. histrix loricata (B 20 107666). For each taxon, from left to right: megaspore proximal view, megaspore distal view, megaspore equatorial view (except for the last line, where the last image is an overview of several megaspores). SEM micrographs of the first two taxa made by AT (in P),

690 micrographs of the last taxon made by AT and Carmela Di Liberto (at the University of 691 Palermo). 